\title{
Factors Affecting Student Learning Motivation During the Covid-19 Pandemic
}

\author{
Ebnovrio Hanesty ${ }^{1}$, Neviyarni ${ }^{2}$, Yeni Karneli ${ }^{3}$ \\ 1,2,3 Universitas Negeri Padang \\ ${ }^{*}$ Corresponding author, e-mail: ebnovriohanesty@ymail.com
}

\begin{abstract}
The last few years have been the most difficult due to Covid-19, a disease that attacks and is transmitted through the human respiratory tract, sweeping the world. As a result, a number of public facilities were closed including schools so that the distance learning model was applied. The condition of the Covid-19 pandemic has made it possible to decrease student learning motivation which is the key to student learning success. Thus, it is important to study the factors that affect student learning motivation. This study aims to describe student learning motivation in terms of self-concept support, parental support, subject teachers, guidance and counseling teachers and smartphone facility factors. This type of research is descriptive using quantative methods. The population of this study were students of MTsN 2 Pesisir Selatan, totaling 711 students, with a sample of 256 students who were taken using a proportional stratified random sampling technique. The results of the study found that in general the learning motivation of MTsN 2 Pesisir Selatan students during the Covid-19 pandemic was in the moderate category, which means that most students lost their motivation to learn.
\end{abstract}

Keywords: Learning Motivation, Covid-19

How to Cite: Hanesty, E., Neviyarni, N., Karneli, Y. (2020). Factors Affecting Student Learning Motivation During the Covid-19 Pandemic. International Journal of Applied Counseling and Social Sciences. 2 (1): pp. 100-107. DOI: https://doi.org/10.24036/005404ijaccs

\section{Introduction}

The 2020 seems to be the most difficult year in the course of global history (Nurfajriani, 2020). The reason is, the outbreak of a disease caused by the spread of a new type of virus that occurred at the end of December 2019 in Wuhan City, China, resulted in paralyzing the economic wheels of many countries in the world. Known as Covid-19 (Corona Virus Disease 2019), a disease that attacks and is transmitted through the human respiratory tract (Rothan \& Byrareddy, 2020) continues to expand its area of spread and hit countries in the world (Salsabila et al., 2020).

Indonesia, as one of the countries with high global mobility, is also the area affected by the spread of the virus outbreak. As is known, on March 2, 2020, Indonesia reported 2 cases of Covid-19 confirmation (Tosepu et al., 2020). As a result of this, a number of public facilities related to mobility and crowd activities between people were closed, including formal education such as schools (Chryshna, 2020). The government also through the Ministry of Education and Culture (Kemendikbud) issued a circular regarding learning from home settings using a distance learning model (Ministry of Education and Culture Circular No.4, 2020). 
Distance learning is learning using technology competency development and electronic communication (Taufik, 2019). Better known in the scientific literature as e-Learning, this distance learning seeks to combine the principles of the learning process with the technology in it (Chandrawati, 2010). The internet is a link related to accessibility, connectivity, flexibility, and the ability to bring up various types of interactions in learning (Moore, Dickson-Deane, \& Galyen, 2011).

The application of distance learning has resulted in a shift in the learning culture (Chandrawati, 2010). As stated by Sari et al. (2020), initially learning was carried out face-to-face in class, it shifted to remote using an online system. Teachers and students are required to be ready in existing distance learning (Tîrziu \& Vrabie, 2015).

In this regard, Madrasah Tsanawiyah Negeri (hereinafter abbreviated as MTsN) 2 Pesisir Selatan has also implemented this distance learning system. Based on the Directorate General of Education Circular Letter No. 285.1 (2020) concerning Efforts to Prevent the Spread of Covid-19, that the implementation of teaching and learning activities and examination activities in madrasah is in line with policies set by the local Regional Government.

Since MTsN 2 Pesisir Selatan is under the policy of the Regional Government of the Pesisir Selatan, in making learning policies according to the decisions of the Pesisir Selatan District Head regarding learning instructions at home (Decree of the Regent of Pesisir Selatan No. 420/518 / DPK / Sekretariat.01 / 2020 ; Top West Sumatra, 2020). As a result, starting March 22, 2020, as many as 683 students of MTsN 2 Pesisir Selatan have to study at home (MTsN 2 Pesisir Selatan Administrative Data, 2019-2020, 2020).

When examining related learning, in essence, it is an activity carried out by a person to obtain a change in behavior as a whole, as a result of his own experience in interaction with his environment (Slameto, 2010: 2). A person who learns will experience changes in behavior as a result of his learning activities (Prayitno, 2009).

Even by studying, it is possible for a person to be able to develop self-potential that is in line with educational values related to aspects of religious spiritual strength, self-control, personality, intelligence, noble morals, and skills needed for himself, society, nation and state (Undang-Undang Republik Indonesia No. 20, 2003). Regarding this, students are expected to always achieve maximum learning success. Therefore, an encouragement in learning is needed for students to achieve their learning success. The encouragement referred to in the scientific literature is known as motivation (Purwanto (2007).

Motivation is a process that provides enthusiasm, direction, and behavior persistence, in which this motivation provides an impetus or driving force (Santrock, 2009). Associated with learning, motivation contains meaning as an encouragement in the individual that appears in the form of behavior to achieve goals in learning (Suryadi et al., 2020).

Motivation also has an important role in learning, because motivation causes students to step, keeps students moving, and determines where students are trying to go (Slavin, 2011). In fact, students who have strong motivation will have a lot of energy to carry out learning activities (Sardiman, 2007).

Janah et al. (2015) further revealed that students' high learning motivation is indicated by the attention, concentration, and persistence of students. Motivation to learn is able to direct oneself and control one's behavior so that it shows the value of obedience, obedience, regularity and order. This means that motivation is so important for one's learning success (Waruwu, 2006), especially students in their learning activities.

However, if it is related to the conditions of the Covid-19 pandemic, it seems that the attention, concentration and persistence of students in learning do not meet the expectations of learning objectives. This is evidenced by the results of Robandi and Mudjiran's research on junior high school students in the City of Bukittinggi in 2020, which found that most junior high school students in Bukittinggi City had sufficient motivation to learn in the 38\% category, then the moderate category 
was $27 \%$, the low category was $24 \%$, and only $11 . \%$ of junior high school students in Bukittinggi City who have high learning motivation during the Covid-19 Pandemic (Robandi and Mudjiran, 2020).

This can also be seen in MTsN 2 Pesisir Selatan students, where student learning outcomes in two semesters during the Covid-19 pandemic, ranging from the application of distance learning to semidistance learning have never achieved satisfactory results. Even for learning outcomes in the JulyDecember semester of the 2020-2021 academic year, the teacher was forced to impose sanctions on students in the form of granting learning scores below the minimum completeness criteria (KKM) (Decision of the MTsN 2 Pesisir Selatan Teacher Meeting Semester I for the 2020-2021 Academic Year Period, 2020).

In addition, students who have not completed their assignments in the July-December semester are not given a semester report card. This step is taken as an anticipatory future, in order to cause a deterrent effect for students who are lacking in completing their responsibilities, starting from not doing the assignments given by the teacher, tending to be lazy, and not caring about anything related to the learning activities they are going through.

In addition to this phenomenon, another phenomenon related to the existence of smartphones (smart phones) as a medium that should facilitate them during the implementation of distance learning (Maknuni, 2020) is misused. On average, students prefer to play social media, online games, or listen to music on their smartphones rather than having to do assignments or relate to learning activities. In fact, in order to be able to buy internet quotas to play online games or play social media, they deceive their parents who give full social support to them. This is certainly unusual and is a sad phenomenon in the development of the quality of the nation's children.

Based on a review of the phenomena mentioned above, it appears that students' learning motivation needs to be reviewed. The role of counseling guidance is also needed in dealing with these problems. As Hikmawati (2012: 15) states that the implementation of counseling in schools is about facilitating the counselee (students as students) to be able to develop their potential or achieve their developmental tasks (regarding physical, emotional, intellectual, social, and moral spiritual aspects). Through the field of learning activities, counseling can play the role and function of its expertise in developing learning motivation.

Implications for service delivery, there are various types of counseling guidance services intended for counselees, such as: (1) orientation services, (2) information services, (3) placement and distribution services, (4) content mastery services, (5) counseling services individuals, (6) group guidance services, (7) group counseling services, (8) consulting services, (9) mediation services and (10) advocacy services (Prayitno, 2012). Counseling guidance teachers as counseling guidance service providers can provide services according to the problems experienced by the counselee. So that the state of the counselee who is KES-T (daily effective life is disturbed) can change to KES (effective daily life).

Departing from the descriptions of these thoughts and phenomena, the researcher feels important and intends to conduct a study by emphasizing the research variables which will be formulated through the title " Factors Affecting Student Learning Motivation during the Covid-19 Pandemic and Their Implications for Guidance and Counseling Services ".

\section{Method}

This type of research is descriptive using quantative methods. The population of this study were students of MTsN 2 Pesisir Selatan, totaling 711 students, with a sample of 256 students who were taken using a proportional stratified random sampling technique. The instrument used was the Likert scale model. Data were analyzed using descriptive statistics. Data analysis was assisted by using the SPSS version 20.00 program. 


\section{Results and Discussion}

The results of the study attempt to describe the descriptions of the research questions regarding the factors that affect student learning motivation during the Covid-19 pandemic with a coverage of factors: (1) self-concept support, (2) parental support, (3) subject teacher support, (4) teacher support for guidance and counseling and (5) support for smartphone facilities.

1. Student Learning Motivation during the Covid-19 Pandemic in terms of self-concept support factors

The description of student learning motivation in terms of self-concept support factors with 256 students as respondents.

Table 1. Distribution of Frequency and Percentage of Student Learning Motivation during the Covid-19 Pandemic in terms of self-concept support factors

\begin{tabular}{lccc}
\hline $\begin{array}{c}\text { Category } \\
\text { Self-concept support }\end{array}$ & Interval & $\mathrm{f}$ & $\%$ \\
\hline Very High & $\geq 84$ & 16 & 6,25 \\
High & $68-83$ & 47 & 18,36 \\
Moderate & $52-67$ & 84 & 32,81 \\
Low & $36-51$ & 74 & 28,91 \\
Very Low & $\leq 35$ & 35 & 13,67 \\
& & 256 & 100 \\
\hline
\end{tabular}

Table 1 shows that student learning motivation during the Covid-19 pandemic in terms of self-concept support factors was mostly dominated by respondents who were in the medium category with a percentage of $32.81 \%$ (84 students). Meanwhile, only $6.25 \%$ (16 students) had very high motivation. Furthermore, self-concept support in the low category is in the second dominance with a percentage gain of $28.91 \%$ (74 students). Meanwhile, for the third domination it was at a percentage of $18.36 \%$ (47 students), namely students with high self-concept support categories in learning motivation.

2. Student Learning Motivation during the Covid-19 Pandemic in terms of Parental Support Factors

The description of student learning motivation in terms of parental support factors with 256 students as respondents.

Tabel 2. Distribution of Frequency and Percentage of Learning Motivation Students during the Covid-19 Pandemic in terms of Parental Support Factors

\begin{tabular}{lccc}
\hline \multicolumn{1}{c}{$\begin{array}{c}\text { Category } \\
\text { Parental Support }\end{array}$} & Interval & $\mathrm{f}$ & $\%$ \\
\hline Very High & $\geq 84$ & 15 & 5,86 \\
High & $68-83$ & 98 & 38,28 \\
Moderate & $52-67$ & 70 & 27,34 \\
Low & $36-51$ & 72 & 28,13 \\
Very Low & $\leq 35$ & 1 & 0,39 \\
& & 256 & 100 \\
\hline
\end{tabular}

Table 2 shows that student learning motivation during the Covid-19 pandemic in terms of parental support factors was mostly dominated by respondents who were in the high category 
with a percentage achievement of $38.28 \%$ (98 students). Furthermore, parental support in the low category is in the second dominance with a percentage of $28.13 \%$ (72 students). Furthermore, the third domination was not too far from the second domination, namely obtaining a percentage of $27.34 \%$ (70 students) in the medium category. Then in the very high category with a percentage of $5.38 \%$ (15 students) and only $0.39 \%$ of respondents who are in the very low category ( 1 student).

3. Student Learning Motivation during the Covid-19 Pandemic in terms of Subject Teacher Support Factors

The description of student learning motivation in terms of the subject teacher support factors with 256 students as respondents.

Table 3. Distribution of Frequency and Percentage of Student Learning Motivation during the Covid-19 Pandemic in terms of Subject Teacher Support Factors

\begin{tabular}{lccc}
\hline \multicolumn{1}{c}{$\begin{array}{c}\text { Category } \\
\text { Subject Teacher Support }\end{array}$} & Interval & $\mathrm{f}$ & $\%$ \\
\hline Very High & $\geq 84$ & 107 & 41,8 \\
High & $68-83$ & 68 & 26,56 \\
Moderate & $52-67$ & 60 & 23,44 \\
Low & $36-51$ & 20 & 7,81 \\
Very Low & $\leq 35$ & 1 & 0,39 \\
& & 256 & 100 \\
\hline
\end{tabular}

Table 3 shows that student learning motivation during the Covid-19 pandemic in terms of support for subject teachers mostly received very high gains with a percentage of $41.8 \%$ (107 students). Then for the next percentage is in the high category with a percentage of $26.56 \%$ (68 students). Furthermore, the moderate category got a percentage of $23.44 \%$ (60 students), the low category was $7.81 \%$ ( 20 students), and $0.39 \%$ for the very low category (1 student).

4. Student Learning Motivation during the Covid-19 Pandemic in terms of Teacher Support Factors, Guidance and Counseling

The description of student learning motivation in terms of the guidance and counseling teacher support factors with 256 students as respondents.

Table 4. Distribution of Frequency and Percentage of Student Motivation during the Covid-19 Pandemic in terms of Teacher Support Factors Guidance and Counseling

\begin{tabular}{lccc}
\hline $\begin{array}{c}\text { Category } \\
\text { Teacher Support for } \\
\text { Guidance and Counseling }\end{array}$ & Interval & $\mathrm{f}$ & $\%$ \\
\hline Very High & $\geq 84$ & 13 & 5,08 \\
High & $68-83$ & 84 & 32,81 \\
Moderate & $52-67$ & 71 & 27,73 \\
Low & $36-51$ & 81 & 31,64 \\
Very Low & $\leq 35$ & 7 & 2,73 \\
& & 256 & 100 \\
\hline
\end{tabular}

Table 4 shows that student motivation during the Covid-19 pandemic in terms of the support factors for guidance and counseling teachers mostly received high gains with a 
percentage of $32.81 \%$ (84 students). But on the other hand, the support of guidance and counseling teachers obtained a percentage of $31.64 \%$ with a low category (81 students). Then for the next percentage is in the medium category with a percentage of $27.73 \%$ ( 71 students). Furthermore, the very high category was $23.44 \%$ (13 students), and the very low category was $2.73 \%$ (7 students).

5. Student Learning Motivation during the Covid-19 Pandemic in terms of Smartphone Facility Support Factors

The description of student learning motivation in terms of support factors for smartphone facilities with 256 students as respondents.

Table 5. Distribution of Frequency and Percentage of Student Motivation during the Covid-19 Pandemic in terms of Smartphone Facility Support Factors

\begin{tabular}{lccc}
\hline $\begin{array}{c}\text { Category } \\
\text { Smartphone Facility } \\
\text { Support }\end{array}$ & Interval & f & $\%$ \\
\hline Very High & $\geq 84$ & 1 & 0,39 \\
High & $68-83$ & 27 & 10,55 \\
Moderate & $52-67$ & 46 & 17,97 \\
Low & $36-51$ & 101 & 39,45 \\
Very Low & $\leq 35$ & 81 & 31,64 \\
& & 256 & 100 \\
\hline
\end{tabular}

Table 5 shows that student learning motivation during the Covid-19 pandemic in terms of the Support Factors smartphone facilities were mostly dominated by low category respondents. This is based on the findings of the percentage for the low category of $39.45 \%$ (101 students). Even for the next domination, the choice was dominated by respondents with a very low category with a percentage of $31.64 \%$ (81 students) and continued with respondents in the medium category with a percentage gain of $17.97 \%$ (46 students). Meanwhile, on the other hand, for respondents with high and very high categories, the percentage gain was not that big and only $10.55 \%$ ( 27 students) were in the high category and $0.93 \%$ ( 1 student) for the very high category.

\section{Conclusion}

Based on the results and discussion of the research, the researcher can conclude that the general learning motivation of students during the Covid-19 pandemic is in the medium category. This means that the Covid-19 pandemic has made most students lose their motivation to learn. The detailed description is as follows.

1. Student learning motivation during the Covid-19 pandemic in terms of support for self-concept is in the medium category. This means that the Covid-19 pandemic leaves students in doubt about the ideal concept for themselves in the face of the Covid-19 pandemic.

2. Student learning motivation during the Covid-19 pandemic in terms of parental support is in the medium category. That is, the tendency for parental support as a factor that has a role in increasing student motivation during the Covid-19 pandemic tends to play a role even though some others are not good enough.

3. Student learning motivation during the Covid-19 pandemic in terms of the subject teacher support factors was in the medium category. This means that subject teachers do not really provide full support in fostering student motivation during the Covid-19 pandemic. 
4. Student learning motivation during the Covid-19 pandemic in terms of the guidance and counseling teacher support factors is in the medium category. This means that guidance and counseling teachers have sufficiently contributed to student learning motivation during the Covid-19 pandemic even though it was not so optimal.

5. Student learning motivation during the Covid-19 pandemic in terms of support for smartphone facilities is in the low category. This means that most students do not use smartphone facilities to support student learning motivation during the Covid-19 pandemic.

\section{References}

Chandrawati, S. R. 2010. Pemamfaatan e-learning dalam pembelajaran. Jurnal Cakrawala Kependidikan. jurnal.untan.ac.id.

Chryshna, M. 2020. Kebijakan pendidikan formal anak pada masa pandemi covid-19. Artikel Berita Online. kompaspedia.kompas.id (diakses pada 13 Juli 2020).

Data Administratif MTsN 2 Pesisir Selatan, 2019-2020. 2020. Data siswa MTsN 2 Pesisir Selatan periode pembelajaran 2019-2020.

Hikmawati, F. 2012. Bimbingan konseling edisi revisi. Jakarta: Rajawali Press.

Janah, N., Mudjiran, M., Nirwana, H. 2015. Hubungan kecanduan game dengan motivasi belajar siswa dan implikasinya terhadap bimbingan dan konseling. Konselor. 4(4), 200-2007.

Maknuni, J. 2020. Pengaruh media belajar smartphone terhadap belajar siswa di era pandemi covid-19. Indonesian Education Administration and Leadership Journal (IDEAL). 2(2), 94-106. https://online- journal.unja.ac.id/index.php/IDEAL.

Moore, J. L. Dickson-Dane, C., \& Galyen, K. 2011. E-learning, online, learning, and distance learning environments: are they the same? internet and higher education. https://doi.org.1016/j.iheduc.2010.10.001

Nurfajriani, R. 2020. Selain corona dan bencana lain, peneliti prediksi 2020 akan jadi salah satu tahun terpanas. Artikel Berita Online. Pikiran-rakyat.com (Diakses pada 11 Juli 2020)

Prayitno. 2009. Dasar teori dan praktis pendidikan. Jakarta: Grasindo.

Prayitno. 2012. Jenis layanan dan kegiatan pendukung konseling. Padang: FIP Universitas Negeri Padang.

Purwanto, N. 2007. Psikologi pendidikan. Bandung: Sinar Baru Algesindo.

Robandi, D., \& Mudjiran, M. 2020. Dampak pembelajaran dari masa pandemi covid-19 terhadap motivasi belajar siswa SMP di Kota Bukittinggi. Jurnal Pendidikan Tambusai. 4 (3), 3494-3502.

Rothan, H. A., \& Byrareddy, S. N. 2020. The epidemiology and pathogenesis of coronavirus disease (covid19) outbreak. Journal of Autoimmunity. https://doi.org/10.1016/j.jaut.2020.102433.

Salsabila, H., Unik, Sari, L. I., Lathif, K. H., Lestari, A. P. \& Ayuning, A. 2020. Peran teknologi dalam pembelajaran di masa pandemi covid-19. Al-Mutharahah. 17(2), 188-198. https://doi.org/10.46781/almutharahah.v17i2.138.

Santrock, J. W. 2009. Perkembangan anak (edisi 11). Jakarta: Erlangga.

Sardiman A. M. 2007. Interaksi dan motivasi belajar mengajar. Jakarta: Raja Grafindo Persada.

Sari, W., Rifki, A. M. \& Karmila, M. 2020. Analisis kebijakan pendidikan terkait implementasi pembelajaran jarak jauh pada masa darurat covid 19. Jurnal

Mappesona. 2(2), 1-13. jurnal.iain-bone.ac.id.

Slameto. 2010. Belajar \& faktor-faktor yang mempengaruhi. Jakarta: Rineka Cipta.

Slavin, R. E. 2011. Psikologi pendidikan (edisi kesembilan jilid 2). Terjemahan oleh Marianto Samosir. Jakarta: Indeks.

Surat Edaran Ditjen Pendis No. 285.1.2020. Upaya pencegahan penyebaran covid-19.

Surat Edaran Kementerian Pendidikan dan Kebudayaan No. 4. 2020. Pelaksanaan kebijakan pendidikan dalam masa darurat penyebaran covid.

Surat Keputusan Bupati Pesisir Selatan No. 420/518/DPK/Sekretariat.01/2020.2020. Penanganan dampak virus corona. 
Suryadi, Triyono, Nur, A. \& Dianto, M. 2020. Hubungan penyesuaian diri,motivasi belajar dengan prestasi belajar siswa. Jurnal Neo Konseling: 2 (1), 1-9. http://neo.ppj.unp.ac.id/index.php/neo.

Taufik, A. 2019. Perspektif tentang perkembangan sistem pembelajaran jarak jauh di Kabupaten Kutai Kartanegara Kalimantan Timur. Jurnal Pendidikan 3(2), 88-98. http://doi.org/10.28926/.

Tîrziu, A. M. \& Vrabie, C. 2015. Education 2.0: e-learning methods. Procedia- Social and Behavioral Sciences. 18(6), 376-380. https://doi.org/10.1016/j.sbspro.2015.04.213.

Tosepu, R., Effendy, D.S., \& Ahmad, L.O.A.I. 2020. Public Health of Indonesia. 6(2), 70-71. http://stikbar.org/ycabpublisher/index.php/PHI/index

Waruwu, F. E. 2006. Belajar dan motivasi: bagaimana meningkatkan motivasi internal. Jurnal Provitae.2(2), 21-25. 